Nonfamily Employees' Perceptions of Person-Organization Fit and Voluntary Turnover in Family Firms

By: Tim Barnett and Esra Memili.

Memili, E. \& Barnett, T. 2008. Nonfamily employees' perceptions of person-organization fit and voluntary turnover in family firms. Best Paper Proceedings of Academy of Management.

Made available courtesy of Academy of Management:

http://dx.doi.org/10.5465/AMBPP.2008.33650251

****() Academy of Management. Reprinted with permission. No further reproduction is authorized without written permission from Academy of Management. This version of the document is not the version of record. Figures and/or pictures may be missing from this format of the document. ***

\begin{abstract}
:
The article investigates the employment of non-family employees by family firms. The opinions such employees hold regarding the procedures and policies of such firms, and the impact of these opinions on employee turnover, are analyzed. Theories of person-organization fit and stewardship are used to explain the effects of family influence on non-family employees' perceptions. It is said that up to two-thirds of all businesses may be owned or managed by family groups. The distinctive features of such arrangements, in terms of both facilitation and restriction, are addressed.
\end{abstract}

Keywords: family-owned business enterprises | employees - attitudes | labor turnover | personnel management | attitude (psychology) | business enterprises

Article:

***Note: Full text of article below 


\title{
NONFAMILY EMPLOYEES' PERCEPTIONS OF PERSON-ORGANIZATION FIT AND VOLUNTARY TURNOVER IN FAMILY FIRMS
}

\author{
ESRA MEMILI \\ College of Business and Industry \\ Department of Management and Information Systems \\ Box 9581 \\ Mississippi State, MS 39762 \\ TIM BARNETT \\ Mississippi State University

\section{INTRODUCTION}

Family firms are a dominant form of organization in the United States and around the world, with some estimates suggesting that two-thirds of business enterprises are family owned and/or managed (Gersick et al., 1997). Despite the inherent differences in the level and type of family influence between family and nonfamily firms and among family firms themselves, family influence is not usually considered in organizational studies, which limits the generalization of findings and leads to ambiguity in both theory and practice regarding crucial family business issues (Dyer, 2003).

One such issue faced by many family firms is the employment, effective management, and retention of nonfamily employees (Hoy \& Verser, 1994). Indeed, many family firms employ more nonfamily employees than family members (Deloitte and Touche, 1999). Hence, fostering positive perceptions, attitudes, and behaviors among nonfamily employees may be critically important if family firms are to attain and maintain cognitive diversity in strategic decisionmaking and achieve long-term success (Amason, 1996; Chrisman et al., 2003).

Nonfamily employees' perceptions regarding family firms' policies and procedures have been identified as a potentially important determinant of nonfamily employees' attitudes and behaviors (e.g., Barnett \& Kellermanns, 2006). Although Barnett and Kellermanns (2006) provided a model illustrating how family influences nonfamily employees' perceptions, attitudes, and behaviors, their model was general in nature and did not focus extensively on specific examples of family influence and how these might impact the perceptions and attitudes.

To fill this gap, we draw upon theories of stewardship and person-organization fit to explore the effects of facilitative family influence, such as reciprocal altruism (Chrisman et al., 2005) and socialization (Chatman, 1989, 1991) and the effects of restrictive family influence, such as relational conflict (Kellermanns \& Eddleston, 2004) and value creation goals (Chrisman et al., 2003). We look at how these phenomena may affect nonfamily employees' perceptions of person-organization fit, as well as nonfamily employees' attitudes and behaviors related to a key organizational outcome, employee turnover. Thus, this paper contributes to the literature by identifying the effects of facilitative and restrictive family influence on the formation of nonfamily employees' perceptions of P-O fit, and the subsequent impact on turnover intentions and voluntary turnover, as shown in Figure 1.

Insert Figure 1 about here 


\section{THEORETICAL BACKGROUND}

Stewardship theory draws on socio-psychological perspectives to study relations in organizations where members are collectivists, in the sense that they value cooperative behaviors more than behaviors driven by self-interest (Davis et al., 1997). Thus, the individuals' interests tend to be aligned with the interests of the organization, which would suggest that "proorganizational collectivistic behaviors have higher utility than individualistic self-serving behaviors" (Davis et al., 1997: 24). Stewardship approaches to the study of firms might be particularly relevant within the context of family firms, as family firm members may hold family firm objectives higher than their individual objectives (Zahra, 2003).

Person-organization (P-O) fit research addresses the compatibility between individuals and organizations through the congruence between the norms and values of organizations and people (Kristof, 1996). A two-way exchange of values is likely in organizations with the possibility of both the individual's values changing and organizational value systems' changing due to the influence of its members (Chatman, 1989). If a two-way adaptation is not achieved, then the individual is more likely to leave the organization. The last option is not what family firms hope for when they aim growth and long-term survival with the involvement of nonfamily employees who are often in large numbers and/or in key positions within family firms.

In family firms, extensive reliance on family members as employees and/or managers can lead to having suboptimal employees with limited quality and quantity of human capital (Dunn, 1995). At the same time, high-capability nonfamily managers might also prefer non-family firms due to presumptions of exclusive treatment of family business members, limitations in career growth and professionalism, and disproportionate wealth transfer in family firms (Sirmon \& Hitt, 2003). Therefore, attracting and maintaining qualified nonfamily employees is a challenging task in family firms, highlighting the importance of human resources management (Barnett \& Kellermanns, 2006). Since perceptions of P-O fit are a major predictor of turnover intentions and voluntary turnover (Kristof-Brown et al., 2005), family firms can utilize nonfamily employees' perceptions of P-O fit as a tool to understand voluntary turnover among nonfamily employees, take preventive measures, and foster a work environment with minimized negative perceptions of P-O fit.

Reciprocal altruism and P-O fit. Reciprocal altruism is a mutual moral value motivating individuals to act in a manner that benefits other individuals without expecting anything in return (Schulze et al, 2002). When family business members are reciprocally altruistic to each other, their interests may be aligned with the interests of the family firm and family business members may hold business objectives above their personal objectives (Chrisman et al., 2005, Zahra, 2003). Additionally, a recent study by Karra et al. (2006) has shown that reciprocal altruism is not limited to the family members only and can be extended to non-kin family business members also. When nonfamily business members are treated as family, a sense of togetherness and reciprocity are enhanced. Hence, nonfamily employees become de facto owners (Stark \& Falk, 1998) of the family business like family member peers. The congruence between the norms and values (Chatman, 1989) of the family business, family business members, and the nonfamily employees is expected to increase compatibility, thereby leading to positive perceptions of P-O fit among nonfamily employees. Thus, 


\section{Proposition 1. Reciprocal altruism extended to nonkin is positively associated with the}

nonfamily employees' perceptions of person-organization fit in family firms.

Relationship conflict and P-O fit. Katz and Kahn (1978: 613) argue that "two systems (persons, groups, organizations) are in conflict when they interact directly in such a way that the actions of one tend to prevent or compel some outcome against the resistance of the other". Recently, studies mostly associate the dysfunctional outcomes of conflict with relationship conflict (Eddleston \& Kellermanns, 2007). Family firms heavily influenced by sociopsychological elements such as ownership dispersion, marital discord, sibling rivalry, and identity conflict (Dyer, 1994) are vulnerable to relationship conflict. Consequently, relationship conflict "destroys the pro-organizational behaviors associated with stewardship" (Eddleston et al., 2007). Family firms deviating from stewardship behaviors such as trust, reciprocal altruism, relational contracts, and non-financial family goals (Corbetta \& Salvato., 2004) become more "conflict prone" (Katz \& Kahn, 1978: 621). When relationship conflict shapes the organizational climate or ideology in family firms, nonfamily employees cannot isolate themselves from the prevalent animosity or hostility. Relationship conflict can lower the overall attention to business needs and harm firm performance (Kellermanns \& Eddleston, 2004). Nonfamily employees are likely to question their compatibility with the antagonistic behaviors and the resulting poor performance in the family firm leading to negative perceptions of P-O fit. Hence,

Proposition 2. Relationship conflict extended to nonkin is negatively associated with the nonfamily employees' perceptions of person-organization fit in family firms.

Value creation goals and P-O fit. Family firms are often driven by noneconomic goals (Chrisman et al., 2003) as well as wealth creation goals (Habbershon et al, 2003). Within the domain of stewardship theory, family business members hold these family business objectives above their personal objectives (Zahra, 2003) and nonfinancial goals are an important component of stewardship behaviors (Corbetta \& Salvato, 2004). However, the pursuit of noneconomic goals might create challenges in human resources management when there are nonfamily employees in family firms. Noneconomic goals may not be explicitly defined or may contradict with individual goals of nonfamily employees harming their stewardship orientations. Accordingly, Barnett and Kellermanns (2006: 844) argue that "high levels of family influence tend to lead to unfair human resources practices in family firms". In this paper, we focus on transgenerational succession (Chrisman et al., 2005), promotion particularism favoring family members (Carney, 2005), and pay dispersion (Pfeffer \& Langton, 1993) as value creation goals in family firms. Chua et al. (2004) argue that most family firms start with a high extent of family involvement and a transgenerational succession goal. As long as there is an eligible family member to fill in the top management position in the family firm, nonfamily employees would not be considered for that position despite their overlapping qualifications. The particularistic employment and promotion decisions favoring family employees can lead to nonfamily employees' negative perceptions of $\mathrm{P}-\mathrm{O}$ fit. A performance-based compensation system is also not applicable in family firms when compensation is utilized to distribute benefits among family members rather than compensating for the actual performance of all employees (Chua et al., 2004). In this type of work environment, nonfamily employees are likely to perceive that they do not fit in the family firm.

Proposition 3. Noneconomic value creation goals of the family members are negatively associated with the nonfamily employees' perceptions of $P$-O fit in family firms. 
Proposition 3a. A transgenerational succession goal of the family business is negatively associated with the nonfamily employees' perceptions of $P$-O fit in family firms. Proposition $3 b$. Promotion particularism favoring family members is negatively associated with the nonfamily employees' perceptions of $P$-O fit in family firms. Proposition 3c. Pay dispersion between family and nonfamily employees is negatively associated with the nonfamily employees' perceptions of $P$-O fit in family firms.

Socialization and P-O fit. Chatman (1991) argues that the socialization process or the organizational social context influences the organization members' values, attitudes, and behaviors over time. Consequently, organizations utilize socialization as a tool to align the new employees' values with the organization's values (Chatman, 1989), which is consistent with the stewardship theory assuming that employees' interests are aligned with the interests of the firm (Davis et al., 1997). Since the founder/owner has the critical influential role in shaping the family firm's vision and culture (Kelly et al., 2000), he/she can provide the broadest cultural information and the family firm historical contexts (Chatman, 1991) through mentoring in case of the hiring and training of nonfamily employees. Hence, learning the family firm values and operating rules from the founder/owner can enhance nonfamily employees' positive perceptions of P-O fit. In addition, formal and informal social events can lead to the social integration (O'Reilly et al., 1989) of nonfamily employees via the development of psychological and social links to family members. Family members' openness to experience (George \& Zhou, 2001) can enhance interactions and socialization with nonfamily employees. Nonfamily employees' proactive orientation (Crant, 2000) can also contribute to the socialization process in family firms. Thereby, nonfamily employees can develop positive perceptions of P-O fit in the family firm.

Proposition 4. Socialization is positively associated with the perceptions of $P$-O fit among nonfamily employees in family firms.

Proposition 4a. Mentoring provided by the founder/owner(s) and/or manager(s) of the family firm is positively associated with the nonfamily employees' perceptions of $P$-O fit in family firms.

Proposition 4b. Social events involving participation of both family and nonfamily members are positively associated with the nonfamily employees' perceptions of $P$-O fit in family firms.

Proposition 4c. Family members' openness to experience is positively associated with the nonfamily employees' perceptions of $P$-O fit in family firms.

Proposition 4d. Proactive orientation of nonfamily employees is positively associated with the nonfamily employees' perceptions of $P$-O fit in family firms.

Turnover intentions among nonfamily employees. Turnover is defined as "the termination of an individual's employment with a given company" (Tett \& Meyer, 1993: 262). When the congruence of nonfamily employees' individual values with family firm values cannot be achieved, nonfamily employees would develop negative perceptions of P-O fit. Consequently, an important attitudinal outcome of nonfamily employees' negative perceptions of P-O fit would be turnover intentions (Arthur et al., 2006; Chatman, 1991; Kristof, 1996; Van Vianen, 2000).

Proposition 5. The perceptions of $P$-O fit among nonfamily employees are negatively associated with turnover intentions among nonfamily employees in family firms. 
Voluntary turnover among nonfamily employees. Negative attitudinal outcomes are expected when there is low congruence between the individual and the organization. Accordingly, nonfamily employees may develop intentions to leave due to low or lack of perceived P-O fit that would make them more prone to actually leave (Arthur et al., 2006).

Proposition 6. The turnover intentions among nonfamily employees are positively associated with voluntary turnover among nonfamily employees in family firms.

\section{DISCUSSION}

There is no question that nonfamily employees face a unique and challenging environment in family firms (Sharma, 2004). The theoretical model presented here links common family firm dynamics (i.e., reciprocal altruism, relationship conflict, value creation goals, and socialization), nonfamily employees' perceptions of $\mathrm{P}-\mathrm{O}$ fit, turnover intentions, and voluntary turnover in family firms. This conceptual framework is provided within the domain of the stewardship and person-organization fit theories.

This paper contributes to the literature in at least two ways. First, it demonstrates the effects of constructive stewardship behaviors (i.e., reciprocal altruism and socialization) and destructive behaviors (i.e., relationship conflict and value creation goals favoring family members) on the formation of nonfamily employees' perceptions of P-O fit in family firms. Second, this paper identifies nonfamily employees' perceptions of $\mathrm{P}-\mathrm{O}$ fit as a major antecedent of turnover intentions leading to voluntary turnover among nonfamily employees in family firms.

\section{LIMITATIONS AND FUTURE RESEARCH IMPLICATIONS}

Studies including nonfamily employees and their perceptions have been rare (except for Barnett \& Kellermanns, 2006). Therefore, determining the antecedents of nonfamily employees' perceptions of $\mathrm{P}-\mathrm{O}$ fit and voluntary turnover among nonfamily employees in family firms is an important step forward.

One limitation of this paper is the assumption of heterogeneity in family firms based on the inclusion of nonfamily employees only. However, family firms also differ in strategic orientations, governance structure, business life-cycles, and culture (Chrisman et al., 2005; Dyer, 1988; Gersick et al., 1997). Future studies should explore the impact of these family firm idiosyncrasies on the perceptions of nonfamily employees and their voluntary turnover. Other antecedents of nonfamily employees' perceptions of P-O fit and nonfamily employees' voluntary turnover are beyond the scope of our paper, however they are worth investigating.

Furthermore, noneconomic goals (Chrisman et al., 2003) in family firms can run counter to nonfamily employees' interests and career aspirations. In this paper, the focus has been on transgenerational succession (Chua et al., 1999), promotion particularism (Carney, 2005), and pay dispersion (Ensley et al., 2007). However, there may be other noneconomic goals that can shed light onto nonfamily employees' perceptions and their voluntary turnover.

In conclusion, the model presented in this paper can help family business practitioners and scholars better understand the unique family firm propensities that affect the nonfamily employees' perceptions and their tenure. If family firms can treat nonfamily employees as family members and provide a harmonious work environment for both family and nonfamily employees by eliminating the dysfunctional elements, they can enhance the family business growth and long-term success. 


\section{REFERENCES AVAILABLE FROM THE AUTHOR(S)}

\section{FIGURE 1}

Family Influence, Nonfamily Employees' Perceptions of P-O Fit,

Turnover Intentions, and Voluntary Turnover in Family Firms

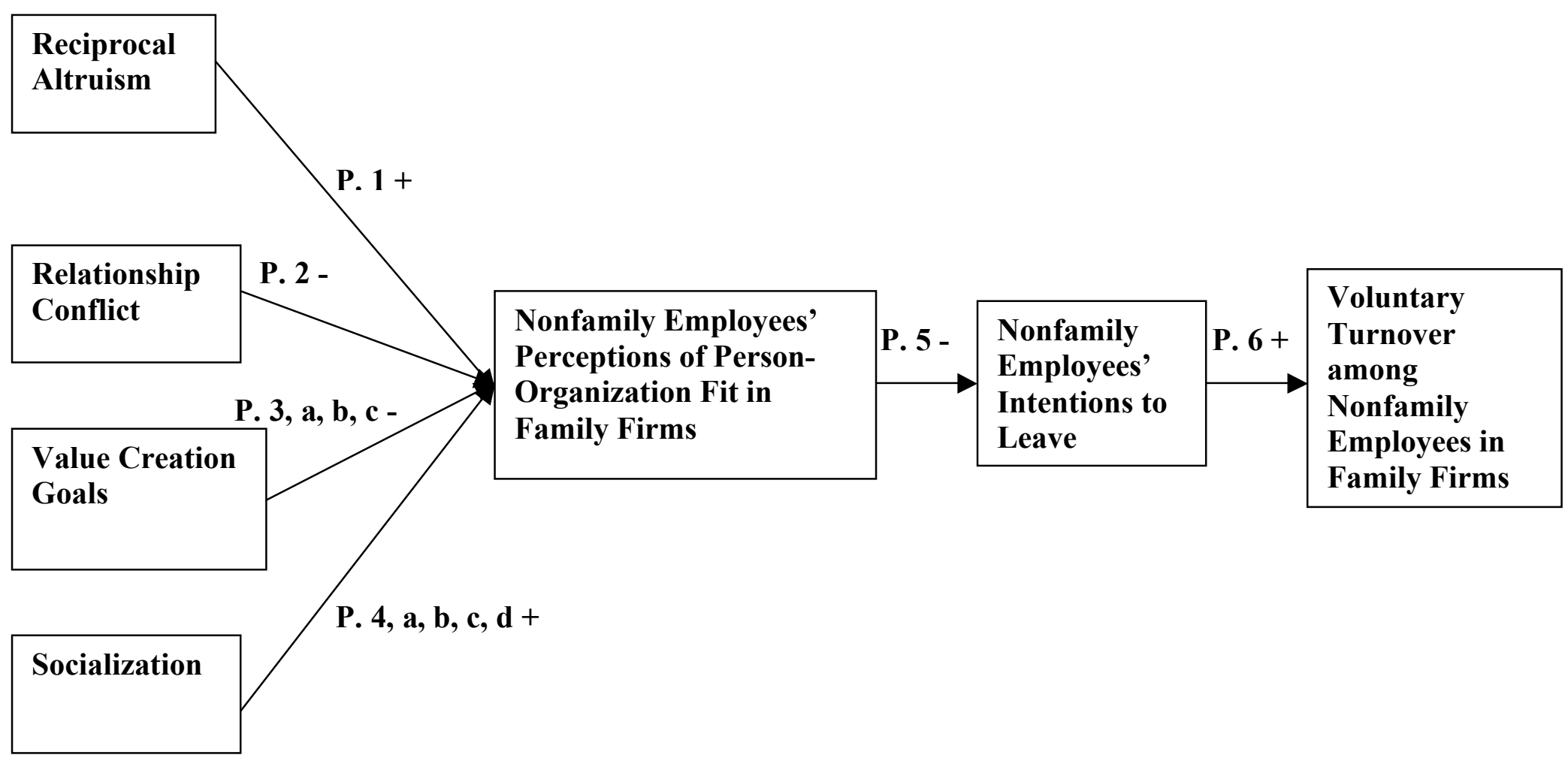


Copyright of Academy of Management Proceedings is the property of Academy of Management and its content may not be copied or emailed to multiple sites or posted to a listserv without the copyright holder's express written permission. However, users may print, download, or email articles for individual use. 
Copyright of Academy of Management Proceedings is the property of Academy of Management and its content may not be copied or emailed to multiple sites or posted to a listserv without the copyright holder's express written permission. However, users may print, download, or email articles for individual use. 
Copyright of Academy of Management Annual Meeting Proceedings is the property of Academy of Management and its content may not be copied or emailed to multiple sites or posted to a listserv without the copyright holder's express written permission. However, users may print, download, or email articles for individual use. 